\title{
Men and gender equality: tackling gender segregation in family roles and in social care jobs
}

Link to publication record in Manchester Research Explorer

\section{Citation for published version (APA):}

Fagan, C., Norman, H., Bettio, F. (Ed.), Plantenga, J. (Ed.), \& Smith, M. (Ed.) (2013). Men and gender equality: tackling gender segregation in family roles and in social care jobs. In Gender and the European Labour Market (pp. 199-223). Routledge.

\section{Published in:}

Gender and the European Labour Market

\section{Citing this paper}

Please note that where the full-text provided on Manchester Research Explorer is the Author Accepted Manuscript or Proof version this may differ from the final Published version. If citing, it is advised that you check and use the publisher's definitive version.

\section{General rights}

Copyright and moral rights for the publications made accessible in the Research Explorer are retained by the authors and/or other copyright owners and it is a condition of accessing publications that users recognise and abide by the legal requirements associated with these rights.

\section{Takedown policy}

If you believe that this document breaches copyright please refer to the University of Manchester's Takedown Procedures [http://man.ac.uk/04Y6Bo] or contact uml.scholarlycommunications@manchester.ac.uk providing relevant details, so we can investigate your claim.

\section{OPEN ACCESS}




\section{Gender and the European Labour Market}

Edited by Francesca Bettio, Janneke Plantenga and Mark Smith 


\section{Contents}

Simultaneously published in the USA and Canada

by Routledge

711 Third Avenue, New York, NY 10017

Routledge is an imprint of the Taylor \& Francis Group, an informa business

(C) 2013 Selection and editorial material, Francesca Bettio, Janneke

Plantenga and Mark Smith; individual chapters, the contributors

The right of Francesca Bettio, Janneke Plantenga and Mark Smith to be identified as the authors of the editorial material, and of the authors for their individual chapters, has been asserted in accordance with sections 77 and 78 of the Copyright, Designs and Patents Act 1988.

All rights reserved. No part of this book may be reprinted or reproduced or utilised in any form or by any electronic, mechanical, or other means, now known or hereafter invented, including photocopying and recording, or in any information storage or retrieval system, without permission in writing from the publishers.

Trademark notice: Product or corporate names may be trademarks or

registered trademarks, and are used only for identification and explanation without intent to infringe.

British Library Cataloguing in Publication Data

A catalogue record for this book is available from the British Library

Library of Congress Cataloging in Publication Data

Gender and the European labour market/edited by Francesca Bettio,

Janneke Plantenga and Mark Smith.

p. $\mathrm{cm}$.

1. Women-Employment-Europe. 2. Sexual division of labor-Europe.

3. Sex discrimination in employment-Europe. 4. Labor market-Europe.

5. Labor policy-Europe. 6. Manpower policy-Europe. I. Bettio, Francesca. II. Plantenga, Janneke, 1956-III. Smith, Mark, 1971 Jan. 26HD6134.G45 2012

331.4094-dc23

ISBN: 978-0-415-66433-2 (hbk)

ISBN: 978-0-203-38611-8 (ebk)

Typeset in Times New Roman

by Wearset Ltd, Boldon, Tyne and Wear

List of illustration

Notes on contributors

Preface

Acknowledgements

1 A new vision of gender equality in Europe?

FRANCESCA BETTIO, JANNEKE PLANTENGA AND

MARK SMITH

\section{PART I}

The economics of gender equality

2 Do we have a cas $€$ for gender equality?

MARK SMITH, A. HAROON AKRAM-LODHI AND

FRANCESCA. BETTIO

3 Measuring gender equality within the European Union

JANNEKE PLANT $\geqq N G A$ AND CHANTAL REMERY

PART II

Care and work in Europe today

4 Unpaid family work in Europe: gender and country differences

FRANCESCA FRANCAVILLA, GIANNA C. GIANNELLI,

LUCIA MANGIAVACCHI AND LUCA PICCOLI

5 Flexible working arrangements and gender equality: categorising the European Member States 
6 Reconciliation of work and private life

JANNEKE PLANTENGA AND CHANTAL REMERY

7 Affordability of care and quality of work: new trends in elderly care

ANNAMARIA SIMONAZZI AND SARA PICCHI

\section{PART III}

Policy: promoting change or eroding equality?

8 The role of the EES in the promotion of gender equality in the labour market: a critical appraisal

PAOLA VILLA

9 Current tax-benefit systems in Europe: are they fair to working women?

FRANCESCA BETTIO AND ALINA VERASHCHAGINA

10 Men and gender equality: tackling gender segregation in family roles and in social care jobs

COLETTE FAGAN AND HELEN NORMAN

11 Recession and recovery: making gender equality part of the solution

MARK SMITH AND PAOLA VILLA

Index

\section{Illustrations}

\section{Figures}

2.1 Per capita GDP growth rates and gender equality

3.1 Scores of the EU-27 on the EUGEI and GII of the UNDP

3.2 Scores of the EU-27 on the EUGEI (four dimensions) and on the EUGEI applying the GII methodology

4.1 Difference between the total work of women and men (aged 20-74) in the EU

4.2 Female family work times and wages by country

4.3 Male family wo:k times and wages by country

5.1 Working time distribution of employees by gender in Hungary, the United Kingclom, France and the Netherlands, 2010

5.2 Share of employees having access to flexible working time arrangements by gender, 2010

5.3 Working time schedules of men and women employees aged 15-64

5.4 Share of employees usually working from home by gender, 2010

5.5 Country scores on equality and flexibility (cumulative z-scores)

6.1 Total employment rate age group 20-64, gender gap in employment rate and EU 2020 target on employment, 2009

6.2 Employment impact of parenthood for women and men aged 20-49, 2009

6.3 Use of formal ard other arrangements, 0-2 years olds, 2009

6.4 Use of formal arrangements by hours, 0-2 years olds, 2009

6.5 Use of formal ard other arrangements, three years to mandatory school age, 2009

6.6 Use of formal arcangements by hours, three years to mandatory school age, 2009

6.7 Effective parental leave in number of months, 2009

7.1 (a) Home and (b) residential care: coverage rates (people over 65), 2008 


\title{
10 Men and gender equality
}

Tackling gender segregation in family roles and in social care jobs

\author{
Colette Fagan and Helen Norman
}

\section{Introduction}

It is essential that men are involved in making the social changes needed to achieve gender equality. An important aspect of this is the development of policy measures to reduce gender inequalities in the domestic division of labour within the home as well as in social care jobs in childcare, eldercare and health.

We start by reviewing men's lower contributions to housework and care work. Such domestic inequality constrains women's employment opportunities and men's involvement in parenting and other aspects of family life. We discuss developments in reconciliation policy in European countries which are designed to enable men to play a more egalitarian role at home, including the recent political agreement at the European level to revise the Parental Leave Directive. ${ }^{1}$

We then turn to address men's under-representation in female-dominated social care jobs. Gender segregated employment creates several labour market problems in this sector, as in other parts of the economy. Research has shown that gender segregation results in the under-utilisation of women's qualifications and experience and the disproportionate concentration of women's employment in the lower-paid parts of the economy, which is a key contributory factor for the gender pay gap (e.g. Bettio and Verashchagina 2009). Gender-segregated employment means that the under-represented sex contends with barriers to occupational entry and progression associated with gender role stereotyping and discrimination, and this inequality of opportunity can exacerbate labour shortages. These problems associated with segregation also apply to men's under-representation in social care roles: gender stereotypes and prejudice are reinforced; labour shortages are exacerbated if men are deterred from entering social care jobs (e.g. in eldercare services); and service-users lack contact with men which may diminish the quality of the service (e.g. a lack of male role models among childcare workers for the children in their care).

A gender-equal society would mean that men and women have the same opportunities and choices about career paths. Furthermore, according to Norwegian research, workplaces with a good gender balance have working environments which exhibit the least conflict or discrimination; thus contributing to higher levels of job satisfaction and well-being (Norwegian Ministry of Children, Equality and Social Inclusion 2009). 


\section{Gender inequalities in the household division of domestic}

\section{labour}

There are gender inequalities in the household division of domestic labour - in terms of housework and care for children and other family members - across all industrialised countries. Over the last 50 years, women's involvement in employment has grown but unpaid domestic work remains a predominantly female responsibility (Gershuny 2000; Crompton 2006; see Chapter 4 in this volume). Table 10.1 shows that in the average week employed women do more than three times the amount of unpaid domestic work than employed men in each age group across the EU-27 countries, Norway and Switzerland.

Men have a higher employment rate than women and work longer average employment hours than employed women. These gender gaps in employment levels are particularly pronounced for parents with dependent children. However, women have the longer 'total working week' when paid and unpaid work hours are summed, with full-time employed women being particularly overburdened (Burchell et al. 2007; Chapter 4 in this volume)

There are national variations in the amount of time spent on domestic work by both sexes, and in the gender gap in contributions (Gershuny 2000; Chapter 4 in this volume). Among employed persons the narrowest gender gap in domestic work is found in Sweden (women do 70 minutes more per day than men); rising to more than two hours per day in Spain, Italy and Poland (Eurostat 2009, adapted from Council of the European Union 2008: 69). Swedish fathers are credited with being more involved in childcare and housework than fathers in any other Western welfare state; a situation which has been nurtured by state policy (Bergman and Hobson 2002).

Across countries the gender gap in time allocated to domestic work has narrowed in recent years as women's participation rates in employment have increased. Much of the adjustment is because women now spend less time on housework, which has been attributed to changing standards of cleanliness, the introduction of labour-saving devices, the ability to 'outsource' the provision of

Table 10.1 Average unpaid weekly working hours of domestic work (housework plus caring for children and adults) by employed men and women by age, 2005 (EU-27 plus Norway and Switzerland)

\begin{tabular}{lll}
\hline Age of respondent & Men & Women \\
\hline 24 years or younger & 3.2 & 10.4 \\
25-39 years & 9.2 & 31.8 \\
40-54 years & 8.6 & 26.9 \\
55 years or older & 5.2 & 17.9 \\
\hline
\end{tabular}

Source: Eurostat (2009: 45).

Note

Total weekly unpaid working hours declared by male and female respondents aged 15 or over based on the fourth European Working Conditions Survey 2005. some housework, use of childcare or eldercare services, as well as more women being in the labour force (Crompton and Lyonette 2008; Nyberg 2003; Bianchi et al. 2000; Craig 2007; Gershuny 2000). The other part of the adjustment is that men have increased their contributions to domestic work. For example, in the UK between 2000 and 2005 the proportion of men who spent some time each day on housework rose from 77 per cent to 86 per cent, while it fell slightly for women from 96 per cent to 92 per cent. The average amount of time spent on housework per day rose by 27 minutes for men and fell by 35 minutes for women, so the gender gap narrowed to 52 minutes per day on average (Lader et al. 2006: 20).

Hook's (2006: 647) analysis of time-use surveys from 20 countries shows a clear increase in men's unpaid work over the period 1965-2003 across all the countries surveyed: overall, married employed fathers have increased the mean time they spend on unpaid work (housework, shopping and childcare) by nearly six hours per week. It is particularly in relation to childcare, rather than housework, that men have become more involved across successive generations, meaning the gender gap has narrowed more so for parenting than for housework (O'Brien 2005). There are also gender differences in the types of domestic tasks carried out in the home, with men tending to focus on playing and putting children to bed, household repairs and general home-improvement jobs. In contrast, women usually take responsibility for the more mundane and time-consuming tasks such as cleaning, shopping, ironing, washing, cooking and the more 'routine' care of children (Spain and Bianchi 1996; Oakley 1985).

Gender inequalites are less pronounced in relation to eldercare than for childcare and housework, but women constitute the majority of informal caregivers across Europe, whi e men represent 'second instance' informal care providers, with their caregiving much more conditional on employment status than it is for women (Bettio and Verashchagina 2010). The gender gap in providing informal care is narrowest among elder persons caring for a spouse (Young et al. 2006; Del Bono et al. 2009). Education and labour market participation are key human capital factors which shape the gender division of domestic labour (Chapter 4). The gender gap in domestic work is narrower when women are employed. Essentially, employed mothers gain more 'bargaining power' to adjust the gender division of unpaid work if their earnings and/or occupational status approach parity with that of their male partner (for a review, see Fagan 2010). Francavilla et al. (Chapter 4) demonstrate the critical impact of education on engagement with housework and childcare across 15 European countries: the gender gap in time allocated to domestic work, as well as employment, is narrower among the hor educated, yet gender gaps in childcare rise with education level. The amount of time parents spend with their children increases with the education level of the parent, but more so for mothers than for fathers.

While women's increased engagement in the labour market is creating pressure for a more gender-equal allocation of domestic tasks in the household, a combination of cultural norms and institutional arrangements create the conditions for the 'stalled revolution' (Hochschild 1989) or 'lagged adaptation' 


\section{C. Fagan and H. Norman}

(Gershuny 2000). Cultural norms concerning family roles and domestic practices adapt slowly across generations. Nonetheless, an attitudinal shift has accompanied the long-term increase in women's labour market participation and across Europe and the United States a growing proportion of the population favour more egalitarian, shared family roles (e.g. Crompton and Lyonette 2008; Scott 2006). This is important since gender role attitudes have been shown to have a significant influence on the domestic division of labour (Benjamin and Sullivan 1997; Marx-Feree 1991). For example, gender-egalitarian attitudes and practices are more likely among men and women if their parents also held genderegalitarian attitudes (Gershuny et al. 1994).

Cultural expectations about fathers' involvement in childcare have also changed across the generations (O'Brien 2005; Bergman and Hobson 2002; Coltrane and Parke 1998; Smeaton 2006; Guardian, 21 February 2009). In many countries, fathers now expect, and are expected, to be emotionally and directly involved with their children as well as making economic contributions to their welfare; nowadays, 'earning as caring' is not enough to validate a 'good father' status (O'Brien et al. 2007: 376; Tanaka and Waldfogel 2007; Norman 2010).

However, domestic labour - particularly housework - has lower social prestige compared to the financial and status rewards of employment, which creates little incentive for men to change their behaviour. Furthermore, housework offers fewer emotional rewards and fun than childcare, and many men do not regard housework as falling within the remit of their father/husband responsibilities (Dermott 2008; Fassinger, cited in Lewis 2002).

Men's reluctance to do housework can be considered a symbolic enactment of their masculinity (Brandth and Kvande 1998: 293; Doucet 2006, Kitterod and Petterson 2006; Hearn 2001). Furthermore, if men are unemployed or low paid and thus cannot fulfil the expected 'manly' responsibilities of the economic provider, then avoiding housework may be the only way to enact their masculinity (Spain and Bianchi 1996: 170; Morris 1985). Women's gender identities are also caught up in this dynamic because doing housework and childcare is widely held to be at the heart of what it means to be a good wife/mother, but is rarely considered to be part of men's competence as a husband/father (Bianchi et al. 2000: 195). Therefore, some women are hesitant to relinquish control in the private sphere and set domestic standards that men consider unacceptably high (Arrighi and Maume 2000). This 'maternal gate keeping' has been regarded as a key determining factor of paternal involvement by some, with fathers' abilities to care for their children partially resting on the mother's acceptance of them as a caregiver (Hatten et al. 2002; Gaertner et al. 2007).

Certainly, men are unlikely to simply substitute domestic work for market work if they lose their jobs. This is illustrated by a recent study of changes in time use in the United States during the recession, which found that men put more time into non-market work and childcare as the time allocated to market work fell due to cutbacks by firms, but the increase was not statistically significant and the time-use reallocation was less than the reduction in market work time (Aguiar et al. 2011). However, Norman (2010) found that in the UK employment hours have a significant association with paternal involvement in childcare and housework when children are very young. Her analysis of over 11,000 households in the UK's Millennium Cohort Study revealed that fathers were more involved in childcare and housework if they worked shorter hours in employment and their partners were employed full-time.

The lack of developed institutional arrangements to help men as well as women reconcile employment with caregiving roles reinforce cultural norms rather than opening up social space for change to emerge. Certainly, the pace and extent of 'lagged adaptation' varies between countries and can at least in part be attributed to policy intervention. For example, family policy in the Nordic countries includes a focus on increasing fathers' involvement in caring for their children (O'Brien 2009) and has yielded a situation in which Norwegian and Swedish fathers spend more time looking after children compared to fathers in the UK, for example (Sullivan et al. 2009). Hence the influence from institutional arrangements and labour market conditions on family arrangements is significant because they shape the resources and opportunities available to families, and hence their capabilities to develop a more gender-egalitarian domestic arrangement (Hobson et al. 2012).

\section{Developments in reconciliation policy targeted at increasing men's involvement in childcare and domestic labour?}

Reconciliation measures have developed across the EU, primarily with a focus on facilitating womer's employment. Some of the earliest initiatives were under the old socialist systems of Central and Eastern European (CEE) countries, which focused on promoting gender equality in the labour market via leave schemes and collectivised childcare, but did not address gender inequalities within the home. Consequently, women's labour force participation increased after World War II with the 'worker-mother contract' institutionally embedded within communist work regimes. State policy in these countries did not consider the household to be a site of gender conflict, and this reaffirmed the private sphere as a woman's domain while preference was given to men in access to many of the senior positions in organisations and public bodies (Metcalfe and Afanassieva 2005).

The question of men's involvement in care responsibilities has been a fairly recent development in most countries (Stier and Lewin-Epstein 2007: 236; Smith and Williams 2007; O'Brien 2009), and is still largely secondary to the emphasis on their role as economic providers in policy debates (Lewis 2002; Smith and Williams 2007).

The main policy intervention geared towards supporting a greater involvement of men in fami y life is parental leave. There are significant national differences in the origin and detail of schemes. ${ }^{2}$ The first scheme was implemented in Sweden, followed ty the other Nordic countries in the 1970s. Hungary also started developing parental leave at around the same time (Moss and O'Brien 2006), whereas in some countries, for example Ireland and the UK, parental 


\section{C. Fagan and H. Norman}

leave was not introduced until after the 1996 EC Parental Leave Directive (Moss and Deven 1999; Plantenga and Remery 2005, 2009; Fagan and Walthery 2007).

Paternity leave, which is sometimes referred to interchangeably with parental leave, is a different statutory entitlement that enables a father to be absent from work for a period of time immediately after a child is born. It is not a statutory right in every country, but where it exists the provisions tend to be for a period ranging from a few days up to two weeks with a high earnings replacement rate. Exceptions include Poland, where paternity leave extends to four weeks, and the UK, where the two-week period of paternity leave is supported by a flat-rate payment which equates to 20 per cent of earnings on average (COWI 2008; O'Brien 2009). The UK government recently committed to extend paternity leave rights by introducing flexible parental leave and statutory parental pay from 2015 . This will allow an employed father to take part of the mother's maternity leave provided she returns to employment before she has exhausted her full statutory entitlement to maternity pay. The father may take up to six months' leave (26 weeks) on statutory paternity pay ( $£ 135.45$ per week for 2012-13) once the child is 20 weeks old and the leave must be taken before the child's first birthday (HM Government 2012). In Slovenia fathers are entitled to take up to 90 days of paternity leave: 15 days are paid at 100 per cent earnings replacement and must be taken at the same time as the mother is on maternity leave; there is no benefit paid for the other 75 days of leave other than the state funding social security contributions.

Under the Lisbon Process there has been an increasing recognition of the importance of leave arrangements and their impact upon fathers' involvement in childcare and gender inequalities in the labour market. As well as efforts to promote the implementation of the original parental leave directive, for example in the recent case of Hungary (CEC 2009), an important recent development at the European level is the directive which extends parental leave entitlements. ${ }^{3}$ The parental leave entitlement has been extended by one month per parent, which cannot be transferred from one to the other. No EU-level initiative has been taken to introduce a statutory right to paternity leave.

This reform increases the incentive for fathers to take parental leave, but unless Member States supplement the directive requirements with a commitment to support this leave with financial compensation, the actual impact is likely to be modest. This is because fathers' take-up of parental leave is lower than that for mothers in every country. The schemes which stimulate the best take-up rate by fathers are those with a quota of leave reserved for the father underwritten by a high replacement rate for earnings plus flexibility in when and how the leave may be taken (Bruning and Plantenga 1999; Moss and Deven 1999; Fagan and Walthery 2007; COWI 2008; Lohmann et al. 2009: 37). Such schemes provide an incentive for fathers to take parental leave in contrast to family-based allocations that can usually be shared by parents but in practice are mainly taken by mothers and thus serve to reinforce women's traditional roles as the primary carer. Conversely, long and poorly compensated schemes do little to reduce gender inequalities in family-based care arrangements.
The 'daddy quota' helps to promote parental leave as a 'masculine gendered right' (Brandth and Kvande 2009: 186) and is more effective in promoting gender equality in the home than gender-neutral parental leave policies. The perception of leave as a right for fathers is important as a means of making it more acceptable in workplace cultures for fathers to use reconciliation policies; and fathers make more use of parental leave schemes when they have a supportive workplace environment (Moss and Deven 1999; COWI 2008). Conversely, poor labour market conditions such as falling wage evels, job insecurity and unemployment will deter fathers from taking leave (Anxo et al. 2007: 6).

There has been a policy push in Nordic countries to promote men's use of parental leave as part of a wider social policy agenda to increase men's involvement in caring roles. Some of the Nordic initiatives that have been implemented to increase men's involvement in family roles are presented in Box 10.1. The recently reformed parental leave system in Iceland produces the most generous entitlement for fathers in terms of the quota (three months) and economic compensation (80 per cent of salary), which stimulated an increase in fathers' use of parental leave so that Iceland has the most gender-equitable pattern of leavetaking of all the Norcic countries. By 2004, 90 per cent of fathers took parental leave in Iceland (up from 82 per cent in 2001), and the proportion who took more than their minimum quota also increased - from 14.5 per cent in 2001 to 17 per cent in 2004 (Jonsdottir 2008).

\section{Box 10.1 Nordic initiatives to increase men's involvement in} non-traditional family roles

Social policies in the Nordic countries have been important in changing the gendered patterns of breadwinning and caring, given they focus on transforming men into caring fathers. The most prominent policy measure is non-transferable paid parental leave reseived for fathers. Other measures which support fathers' care roles are 'daddy day's' when the child is born and individual rights to paid absence when children are sick. These policies have been instrumental in making Nordic fathers more involved with their children than any generation before.

All the Nordic countries have a 'daddy' quota', i.e. non-transferable parental leave reserved for fathers (except Denmark, where the two-week quota introduced in 1998 was abolished in 2002) with financial support. The quota is three months in Iceland, 2.5 moaths (ten weeks) in Norway as of 2009 and two months in Sweden. In Finland fathers are allotted a daddy month, but with certain provisos: if the father took two weeks at the end of parental leave, he would get two weeks extra as a bonus (Lammi-Taskula 2006). Although the main aim of the quota has been to encourage gender equality in the take-up of leave, establishing a good father-child relationship has also been an important policy rationale.

Daddy quotas have had a clear and direct impact on fathers' take-up of leave. In Iceland, Norway and Sweden about 75-90 per cent of the fathers entitled to the daddy quota take scme leave. In Denmark, during the short period of time that the 'daddy quota' was in operation, the proportion of fathers taking leave rose from 7 per cent to 24 per cent. Moreover, the longer the daddy quota, the higher the 
fathers' share of the total days of leave: in 2005 the highest proportion of leave days taken by fathers occurred in Iceland (32.7 per cent) and Sweden (20.5 per cent), with Norway occupying an intermediary position ( 9.3 per cent). There was a lower engagement by fathers in Denmark ( 5.9 per cent) and Finland ( 5.5 per cent), where the leave arrangements are more limited (Ellingsæter 2009).

Some studies indicate that fathers taking up leave have an impact on the domestic division of labour. Norwegian qualitative studies maintain that when fathers took leave, there was a redefinition and redistribution of domestic tasks, and fathers who were home alone on leave developed their competence as carers (Brandth and Kvande 1998, 2003). Findings from a study of 356 fathers working in large private companies in Sweden showed that the amount of leave days taken had positive effects on several aspects of fathers' participation in childcare and on their satisfaction with contact with children (Haas and Hwang 2008).

There are good reasons for focusing on policies directed at the gender division in the early stages of family formation, for studies indicate that the household division of labour is established early in couples' relationships and is not easily changed (Evertsson and Nermo 2007). Parental leave programmes aim to change the domestic division of labour; however, the full potential of such measures for degendering the division of childcare will not be met until social policy provides stronger incentives for fathers to take a more equal portion of parental leave (Haas and Hwang 2008).

Social policy that offers fathers the chance to take paid leave to be at home with children removes one structural/institutional constraint to their becoming engaged and equal parents, but other significant constraints are likely to remain (Haas and Hwang 2008). One is the quality of mothers' employment opportunities, which have a strong impact on fathers' engagement in childcare. If women's jobs are less well remunerated and less fulfilling, it may reinforce gender-segregated roles and lower men's domestic involvement in care roles. Thus, policies supporting equal employment opportunities for women are needed alongside policies encouraging fathers to take parental leave.

Source: Anne-Lise Ellingsæter, EGGE national expert for Norway

The evaluation of parental leave schemes in the Nordic countries conclude that 'daddy' quotas underwritten by financial compensation have a clear impact on raising fathers' take-up of leave and that the longer quotas in Iceland and Sweden are associated with men taking a higher share of the total parental leave days (Box 10.1). When fathers take parental leave it seems to promote a more gender-equal sharing of domestic roles after the leave period, but it is the length of leave taken by fathers rather than leave itself which provides the conditions for nurturing these changes in gender roles over the longer term. This suggests that generous and gender-specific leave policies help promote a more genderequitable division of unpaid work in the home.

Some research has shown that the shorter periods of paternity leave at the time of birth can also enhance fathers' involvement, even if this is usually in the role as care 'assistant' to the mother while she is at home. For example, a survey of 2,261 fathers in Britain found that just over half (56 per cent) of the fathers who took paternity leave when their last child was born said it allowed them to take a greater role in the care of their children, while 69 per cent said it led to improvements in family life. The most common reason fathers gave for not taking paternity leave was being unable to afford it $^{4}$ (Equality and Human Rights Commission 2009).

Paternity leave is also playing an important role in helping to shift attitudes and behaviour in Portugal, where developments in Portuguese policies have extended fathers' rights in a series of reforms that have increased the length and flexibility of leave, the level of payments and the amount of leave reserved for fathers (Fagan 2010). Thus, while paternity leave may have more limited scope for encouraging gender symmetry compared to longer periods of parental leave (Lammi-Taskula 2006), it still plays an important role for building fathers' involvement in childcare and as a complement to feed into their subsequent use of parental leave.

In comparison to the Nordic examples discussed in Box 10.1, fathers' take-up of parental leave is much lower in most of the other EU and OECD countries (Fagan and Walthery 2007; Moss 2009). This is illustrated by a recent comparison of eight Member States. The Danish system stands out for offering earnings-related compensation during the leave period and achieves the highest take-up rate for fathers, as well as mothers (see Table 10.2); however, fathers' take-up of parental leave is improving in some countries, even if still low by Nordic standards. These improvements are usually triggered by policy reforms which introduce or extend a quota for fathers and/or improve the financial support (Moss 2009).

Germany is one such example, where the proportion of fathers taking parental leave rose steadily from 3.3 per cent in 2002 to 13.7 per cent by the middle of 2008 in the context of parental leave reforms which increased the earnings replacement rate and introduced a daddy quota (Moss 2009). The 2007 Elterngeld reform introduced in January 2007 raised the earnings replacement rate of parental leave benefits to 67 per cent of prior earnings (with an upper monthly limit of $€ 1,800$ ) while shortening the period of paid leave per birth from 24 months to 12 months. Parents also have the option to spread the payment period over 24 months, but at a lower replacement rate of 33 per cent. The reform also introduced a 'daddy month' period to encourage fathers' use of leave: the 12 -month paid leave period is extended by two months providing the father takes a minimum of two months' leave (Maier 2008; Moss 2009: 66).

In Portugal there has also been a recent series of reforms to extend fathers' rights to parental lecve, which have centred on introducing a daddy quota and improving the financial support during parental leave. Fathers' take-up of parental leave has increased with these reforms, but Ferreira argues that further improvements to the parental leave provisions in conjunction with other reforms to education, family and labour market policies are needed to promote gender equality in caregiving (cited in Fagan 2010)

There have been a number of other developments across the rest of the EU to promote fathers' participation in leave arrangements. In some countries only modest steps have been taken, such as in Slovakia where the parental leave 
benefit has been increased to the level of the minimum wage. This may help increase men's use of parental leave, but the low replacement rate does little to incentivise men and women to take leave when they are in higher-paid jobs (Piscová and Bahna 2009). Another example is Poland, where paid paternity leave was implemented in 2010, which although judged to be a small step, is one that is in the right direction. In other countries the focus has only been on women. For example, in Cyprus the government has introduced an option for parental leave entitlements to be transferred from fathers to mothers following low take-up by men; however, this risks reinforcing traditional gender roles within the family (Ellina 2009). Similarly, in Malta reforms have focused on improving maternity rights without measures targeted at men, also implying that reconciliation meastres are only relevant for women. Finally, in Estonia the positive reform which was introduced to encourage greater take-up by fathers has been reversed by making leave unpaid due to the financial stringency of the economic crisis.

While parental leave has been the policy focus for increasing men's involvement in childcare, in some countries this has been part of a wider set of interventions. The Nordic countries are examples of where parental leave policy is complemented by a wider framework of family leave policies which include individual rights for time off to care for sick children that also support fathers' involvement in providing childcare (see Box 10.1). These leave measures have been accompanied by public information campaigns organised by a variety of state, social partner and NGO initiatives to challenge gender stereotypes and encourage fathers to take a larger role in caring for their children.

The Netherlands is another European country of particular interest because of its policy framework, Plan of the man, which promotes a more equal gender division of paid and unpaid work. ${ }^{5}$ Like the Nordic case studies, parental leave is only one part of the policy framework. Parental leave is on a part-time basis with a low level of payment, and the male take-up is much lower than for Dutch women, although higher than in many countries, placing it among the Nordic countries and above Finland. Men, like women, also have the statutory right to request part-time work, but few use this measure for reconciliation purposes. This raises the question of what types of working time adjustment might appeal most to fathers. The Netherlands is one of several countries with the more widely spread availability of working time options that provide employees with flexibility in how they organise their working day and week (Riedman et al. 2006). Such options may be more attractive than a switch to part-time work for fathers seeking to be more involved in domestic tasks and childcare. Developments in the UK lend weight to this suggestion: here the 'right to request' legislation is weaker but permits employees to request a range of adjustment to working hours. Fathers make fewer requests than mothers overall, but their requests are typically for flexibility or changes in their schedules and rarely for a reduction to part-time hours (Facan et al. 2006). These examples indicate that working time regulations which set upper limits on working time and provide more opportunities for individuals to negotiate flexibility through working time adjustments 


\section{C. Fagan and H. Norman}

provide the conditions which give men and women the opportunity to develop a more gender-egalitarian arrangement of childcare and housework.

In this section we have seen that family leave schemes targeted at fathers particular quotas of paid parental leave, but also shorter periods of paternity leave at the time of birth - provide an important institutional support for increasing fathers' involvement in family-based childcare, and promoting more gender equity in the division of household tasks more broadly. The policy push to promote change in household gender roles has been most concerted in the Nordic countries, joined more recently by the Netherlands. There are also some positive policy directions being taken in the reform of parental and paternity leave schemes in a number of other Member States.

However, even under the more progressive Nordic policy framework, women still take the primary responsibility for housework and child rearing, even if the gender gap is narrower than most other countries. For example, a survey in Iceland some years after the parental leave reform revealed that while fathers who had taken leave increased their participation in the home following the leave period, less than one-third felt that their leave period had resulted in a more 'equal standing' in the division of home-based responsibilities in their household (Jonsdottir 2008: 17). Hence, while measures to promote fathers' use of parental leave is a vital step, it will not transform gender roles on its own. Continued efforts to advance gender equality in the labour market, including reducing the gender pay gap, are also necessary. As part of this agenda, the focus on parental leave policy needs to be widened and an integrated working time policy framework developed, wider than the provisions made in the 2003 EU Working-time Directive, which sets 48 hours as the upper limit on the working week and encourages more consideration of employees' reconciliation needs when working time flexibility policies are being devised. A working time policy framework designed to help promote greater gender equality in the home as well as the workplace would include measures which increased opportunities for individual men as well as women to secure working time flexibility that enabled them to better coordinate the time demands of employment with family care responsibilities. It should include targeted initiatives to encourage fathers' takeup of these opportunities, such as campaigns and incentives focused on maledominated workplaces.

\section{Men's under-representation in female-dominated 'social care' occupations}

Men's low involvement in care work within the home is mirrored in their under-representation in social care jobs. While women have made inroads into some male-dominated occupations there has generally been little, if any, movement of men into female-dominated job areas (see Bettio and Varashchagina 2009; and Chapter 8 in this volume). Where men have entered femaledominated job areas it has been because of dramatic economic 'push' factors when unemployment has risen dramatically in male-dominated job areas, or
Men and gender equality 211

rapid change in organisational structures, which have made the job more attractive relative to working conditions in other more traditionally 'male' areas of work (Rubery and Fagan 1993, 1995). For example, at German unification there was some displacernent of women from the financial sector. More generally across countries men have also made some inroads into clerical and administrative work associated with technological change and declining job opportunities in 'heavy industry' elsewhere.

Although unemp oyment in the current recession may compel men to seek employment in some female-dominated job areas (Bruegal 2000: 83), many female-dominated employment areas may become more exposed as cuts start to hit the public sector in some countries (Smith 2009: 7). Projections for the UK, for example, suggest that existing labour market disadvantages by gender, age and disability will persist through the recession (Berthoud 2009). Either way, relying on the economic fall-out of the recession would be a pernicious strategy for reducing gender segregation of the labour market.

The barriers which deter men from entering female-dominated jobs mirror those which deter women from pursuing gender-atypical employment. The first set of barriers concern gender stereotyping. Boys and girls are exposed to gender stereotyping from an early age, which helps perpetuate gender-segregated education and training paths. Even pre-school children have gender stereotyped notions of what jobs men and women do - this narrows the range of careers considered by children from an early age (Gottfredson 1981).

This early exposure to gender stereotyping continues into adulthood. Sexist stereotyping in employment, the media and public life is widespread, and men and women are particularly aware of the prevalence of this in relation to their workplaces (European Commission 2010). Employment, or more generally the 'economic provider' role, is fundamental to the construction of most versions of masculinity and 'what it is to be a man', much more so than the role of employment in women's identities (Morgan, cited in Simpson 2004). Heterosexual masculine identity is constructed in opposition to notions of what constitutes homosexuality as well as femininity, which deters some men from considering certain 'female' occupations since this might call their sexuality into question (Segal 1990). Given the centrality of work to most variants of masculinity, men may feel more normative pressure to follow traditional employment roles in order to avoid ending up with a 'damaged masculinity', while women's perception of their femininity may be less fragile and less reliant upon the jobs they do (Bradley 1993: 14).

Gender stereotyping not only steers men away from applying to enter femaledominated job areas; it can also fuel discrimination against men who do enter non-traditional areas. This is the second set of barriers which can prevent men entering at least some female-dominated job areas. Simpson (2004) argues that certain feminised care jobs are commonly deemed to entail tacit nurturing skills and 'emotional labour' (Hochschild 1989) which women are perceived to be better at than men because women are the primary carers in gender-segregated family roles. Hence men's suitability is often in question in the minds of 


\section{C. Fagan and H. Norman}

employers and clients for many social care jobs connected with childcare, teaching young children, nursing and eldercare. In addition to a discriminatory barrier of stereotyped competence there may be an additional barrier of stigma if they enter certain professions. For example, men working in childcare professions have been viewed with suspicion following high-profile cases of child abuse and paedophilia, including being directly challenged about their motives (Rolfe 2006; Penn and McQuail 1997).

Men employed in non-traditional jobs face the challenge of achieving an appropriate balance of masculinity - similar to the identity dilemmas faced by women employed in male-dominated areas (Wacjman 1998; McDowell 1997). If they are 'too masculine' then their sexual intentions may be called into question or they may be accused of being exploitative. If their masculinity is deemed to be 'too passive' then the common assumption is that they are homosexual, usually conferred with negative homophobic connotations. Men's non-traditional employment choices also often elicit gender-stereotyped responses from family and friends and can incur personal costs in the form of lack of support from kin and friendship networks. More than half of the men in a study of men employed in non-traditional jobs confessed to feeling embarrassed about admitting their job title, and several stated they had lied to avoid the ridicule they anticipated (Cross and Bagilhole 2002).

Another approach is for men to re-label their job in an attempt to remove the feminised association and affirm their masculinity, for example male secretaries being called 'administrative assistants' (Pringle, cited in Lupton 2000). Heikes (1992) found that male nurses reported how they highlighted the scientific skill involved in their jobs to disassociate themselves from the traditional female notions of nursing, including choosing specialities such as psychiatry and anaesthetics purposely as a niche removed from the feminised connotations of general nursing. The reconstruction of the nurse identity enabled the men to retain their masculinity while remaining in a female-dominated profession (Heikes 1992).

The third barrier which operates to curtail men's entry to female-dominated occupations is that many of these jobs, particularly in social care, are low paid, have limited job security, benefits or training opportunities and offer restricted career ladder progression. Furthermore, in countries where part-time employment is widespread, some female-dominated job areas offer few opportunities for full-time hours (Plantenga et al. 2007; Bettio and Verashchagina 2009). The skill requirements in many service and care jobs are often under-valued, in part because they are linked to tasks and 'tacit skills' undertaken by women unpaid in the domestic sphere. For example, childcare is low paid in many countries and this creates recruitment and retention problems (Owen 2003). While this is a problem for recruiting women, it becomes a particularly acute barrier deterring men from entering the profession (Rolfe 2006; Hatten et al. 2002).

While there are cultural, institutional and economic barriers which deter men's entry into non-traditional social care jobs, such employment can also provide men with promotion advantages. Men may be under-represented in the occupation but they are frequently over-represented in the senior and managerial grades so that pronounced gender-based vertical segregation is observed even in female-dominated parts of the economy. This is found, for example, in nursing (Evans 1997; MacDougall 1997; Cross and Bagilhole 2002) and for teachers in elementary and secondary-level schools (Bettio and Verashchagina 2009; Rubery and Fagan 1993). Williams' (1992) study of four female-dominated professions found that men were expected to move up into authority positions, and refers to this process as the 'glass escalator' in contrast to the 'glass ceiling' which women often face. It is for this reason that moves to de-segregate femaledominated job areas also brings the risk of negative effects on career progression for women employed in these areas.

Policy interventions to reduce gender-based segregation have tended to focus on encouraging women into non-traditional jobs. Measures targeted at men are much rarer. Most of these concern the career paths of young people (Bettio and Verashchagina 2009). For example, in Germany there have been motivational events for both girls and boys such as the 'New pathways for boys' which was introduced in April 2008 to provide career and life planning in a 'gender sensitive' way (Advisory Committee on Equal Opportunities between Women and Men 2006). Goals included widening boys' awareness of the range of career opportunities open to them, particularly in the social care and education professions; providing opportunities for boys to develop interpersonal communication and team-working skills that are increasingly in demand in many modern workplace settings; networking existing projects for boys and non-traditional career routes; and to cont:ibute to the development of new conceptual tools and research for understanding boys' lifeplans and aspirations. Liechtenstein and Switzerland have acopted a similar approach; under the initiative 'Women's occupations - men's occupations' boys and girls 'swap' roles for the day, with boys visiting kindergartens and girls visiting technical professions. In Finland the National Thematic Network for De-Segregation in the Labour Market (2003-07) prioritised motivating children and young people to make atypical choices and train teachers and careers councillors to advance gender equality through education. In Iceland the Equal Opportunities Office plans to employ individuals to visit primary schools with the sole purpose of making children and young people aware of gender influences.

There are some examples of positive action measures to recruit men into female-dominated social care jobs (Bettio and Verashchagina 2009). For example, the Federation of Nurses in Iceland ran a media campaign to attract men to the nursing profession, which highlighted the potential opportunity for work within war zones. Since 1998 the UK government has employed a National Childcare Strategy, which has coordinated interventions to advertise and promote the childcare and early years' sector to male employees (Rolfe 2006).

Research has shown that men are more likely to enter female-dominated occupations if the pay and career prospects are improved (Bettio and Verashchagina 2009; Rubery and Fagan 1993, 1995). This has informed some recent policy initiatives to improve training opportunities and career ladders in social care jobs. For example, in Austria and the UK there are moves to 'professionalise' 


\section{C. Fagan and H. Norman}

the social care workforce by improving training, pay and career ladders in order to redress recruitment problems and to make these jobs more attractive to men as well as women. Norway and Denmark have introduced trained 'pedagogues' to work with a broad range of ages of children and across varied settings as a means of attracting more men into the variety of roles available that involve working with children (Cameron et al. 2003). In France one aspect of the ALICE project funded under the EQUAL Community programme focused on how to make care work more attractive for men as well as women, alongside other activities that focused on the place of the father in society and tackling stereotypes and other obstacles to men's more active engagement in parenting (Advisory Committee on Equal Opportunities between Women and Men 2006).

The use of quotas to bring men into female-dominated areas is rare, but one exception is Norway where since 1998 there has been a system of quotas for men to enter pre-primary teacher colleges, along with campaigns aimed at getting men more involved in working with children in pre-school and school settings (Men in ECEC (www.wibnett.co) and Men in Schools (www.menniskolen.no)). The quota system combined with other measures to recruit and retain men has succeeded in raising men's presence in these occupations: between 2003 and 2007 the number of men employed by pre-schools has risen by half, in contrast to a standstill or decline in the other Nordic countries. However, the goal of at least 20 per cent of men among the ECEC workforce that was established in 1996 has still not been reached. The pre-schools/daycare centres that have reached this target have done so through a combination of affirmative action and targeted recruitment and marketing strategies. One study has, however, suggested that the men training on these courses are less motivated than the women, and have selected this training route due to a lack of attractive alternatives (Soldberg, cited in Bettio and Verashchagina 2009). According to the Norwegian government, research is needed to develop better and more systematic knowledge on men's aspirations and experiences as a basis for strengthening the recruitment of men into areas where they are under-represented. This includes new initiatives, without quotas, to develop the recruitment of men to the healthcare professions, partly motivated by the predicted worsening of labour shortages in this area (Norwegian Ministry of Children, Equality and Social Inclusion 2009).

\section{Conclusions}

Gender segregation remains pronounced in the home as well as in the workplace. Across successive generations women's involvement in employment has increased, but the increase in men's participation in childcare and housework has been modest. Domestic labour - housework and care for children and elders - is still predominantly the responsibility of women. A combination of cultural norms, habits and institutional arrangements perpetuate this 'stalled revolution'. State policy is important for easing or obstructing social change through the dynamics of daily life in households.
Reconciliation policies which are designed to increase men's involvement in providing care and doing housework provide the policy settings in which 'egalitarian' rather than 'male breadwinner' family arrangements are more able to emerge. The main policy focus to date is on men as fathers via parental leave entitlements and the shorter paternity leave arrangements which exist in some countries. The parental leave schemes which stimulate the best take-up by fathers are the ones with a quota of leave reserved for the father, underwritten by a high earnings replacement rate and flexibility in when and how the leave may be taken. When fathers take parental leave this seems to promote a more gender-equitable sharing of domestic work after the leave period ends, but the length of leave rather than leave itself provides the conditions for nurturing these changes. The Icelandic, Norwegian and Swedish leave systems perform particularly well on these conditions, as does the Dutch system, and fathers' take-up is improving in some other countries such as Finland, Germany and Portugal following policy reform.

A recent development is the extension of parental leave quotas for each parent in the EU directive. However, unless Member States supplement the directive's requirements with financial compensation for the leave period then fathers' takeup of parental leave is likely to remain low. An important complement to parental leave is provision for paternity leave at the time of birth. In several countries fathers have limited or no statutory paternity leave rights; and an EU-level initiative would provide a useful stimulus to reform of this element of reconciliation policy.

Parental leave is only one part of the family policy framework for promoting a more gender-egalitarian involvement in parenting. Some studies report that men continue to be dissatisfied with the volume and scheduling of their paid work (e.g. Kilkey 2006; Fagan 2003; Equality and Human Rights Commission 2009). Thus long working hours for men seems to limit greater paternal involvement in two-parent households, which suggests that the continued long-hours culture across many European countries should be addressed. Measures which facilitate other working time adjustments are also pertinent. The example of the Netherlands suggests that few fathers seek part-time work despite the 'right to request'. Thus, working time policies that enable men to adjust how they organise their working hours across the day and week may be more useful. This seems to be the lesson from the 'right to request' legislation in the UK, where requests by fathers are usually for more flexibility, different schedules or small reductions in hours rather than switch to part-time working.

Family policy will not transform domestic gender roles on its own: continued efforts to advance gender equality in the labour market, including reducing the gender pay gap, are also needed if men and women are to share their earning and caring responsibilities more equally.

Gender-based employment segregation is a resilient feature of European labour markets. While women have made advances into some previously male-dominated jobs, there has been less movement of men into female-dominated job areas. Social care jobs - childcare, teaching young children, nursing, eldercare - are among those which few men enter. The main barriers which deter men from entering 
female-dominated jobs mirror those which deter women from pursuing genderatypical employment: exposure to gender stereotyping from an early age; cultural notions about what 'proper' men do to provide for their families and discriminatory assumptions about men's nurturing and emotional skills. A major deterrent is also the poor pay and quality of many female-dominated jobs.

Men who enter female-dominated social care jobs typically carve out 'more male' niches of work which emphasise physical or technical effort. This may incur personal costs, including some marginalisation from the social aspects of femaledominated workplaces. However, men also seem to gain from a 'glass escalator' effect on career ladders when they are in the minority, in contrast to the 'glass ceiling' which women often face. Policy initiatives to encourage men into nontraditional jobs are rarer than measures targeted at women. Several countries have initiatives to challenge gender stereotypes among boys and girls and some run media campaigns to attract men into traditionally female-dominated jobs. Norway has introduced quotas to recruit men into early childcare, with some success.

An integrated gender-equality strategy should include a coherent framework for action targeted at men (Advisory Committee on Equal Opportunities between Women and Men 2006). In relation to employment and family roles, this requires measures to challenge gender stereotyping in early education and childcare, which includes action to improve boys' and men's activities to care for themselves and others; tackling gender segregation in education, training and employment in female-dominated jobs as well as male-dominated ones; redressing the male dominance of decision-making positions and the gender pay gap; and developing reconciliation measures which support a more gender-equal sharing of domestic and caring responsibilities. In relation to reconciliation measures action by social partners is required in addition to statutory provisions so that initiatives are developed which promote take-up by fathers, including particular efforts in male-dominated areas of employment. The focus on parenting is an important starting point for policy to provide the conditions which encourage a more gender-equal division of responsibilities in the family, but a wider policy agenda is needed that also addresses how to increase men's involvement in care for elder relatives and other family members, and in housework. The framework of action will also need to address ways of supporting men's active involvement in promoting gender equality, and other important problems such as gender-based violence.

Such a framework must be developed in a way which is integrated and coherent with the wider gender-equality infrastructure. Otherwise there is a risk that a focus on men may detract resources from measures focused on women, or, even empower men in a way that maintains the status quo (Advisory Committee on Equal Opportunities between Women and Men 2006; Council of the European Union 2006). This might take the form of a sub-unit or sub-committee which brings a genderequality focus to men's situations, behaviours and attitudes, such as that which exists in the Finnish Council for Equality. At the EU level a framework on men could be developed as part of the Gender Equality roadmap and might be integrated within a revised set of gender mainstreaming guidelines for the open method of coordination of employment and social inclusion policies and the structural funds.

\section{Notes}

1 The Framework Agreement on Parental Leave, on which the directive is based, was signed by the European social partners (BUSINESSEUROPE, ETUC, CEEP and UEAPME) on 18 June 2009. It revises an earlier agreement from 1995. The new directive will replace Difective $96 / 34 / \mathrm{EC}$, which put into effect the 1995 social partner agreement and established for the first time minimum standards on parental leave at the EU level.

2 By comparison there is more national convergence in the design of maternity leave: in By comparison most OECD countries the statutory maternity leave period is $14-28$ weeks, with an earnings-related payment (70-100 per cent). The only exception is Australia and the United States, where there is no entitlement to paid maternity leave (Moss and O'Brien 2006).

3 Parents will have the right to longer parental leave under new rules agreed by EU ministers on 1 December 2009. The new directive was formally adopted by the EPSCO Council on 8 March 2010 (Council Directive 2010/18/EU) and Member States will have to transpose the new rights into national law within two years. The main changes have to transpose the new rights into national law within two years. The main changes
in the revised Directive on Parental Leave are: (1) each working parent will have the in the revised Direcive on Parental Leave are: (1) each working parent will have the
right to take four months off per child (previously three months); (2) an employee applying for or taking parental leave will be protected from any less favourable treatment for doing so; (3) an employee returning from parental leave will have the right to request changes to their working hours for a limited period; (4) the new rights will apply to all workers, regardless of their type of contract; (5) governments and employers/unions will be obliged to assess the specific needs of parents of adopted children and children with a disability or long-term illness (Council of the European Union 2009, 2010; Official Journal of the European Union 2010).

4 Paternity leave is paid at $£ 135.45$ per week as of April 2012.

5 Men's involvement in non-traditional family roles is on the political agenda in the Netherlands, though not very prominently. Until recently the policy target was that men should perform 40 per cent of the unpaid care tasks in 2010, but this was explicitly abolished in the most recent policy note on emancipation, which argued that the government should not intervene in the division of care tasks between men and women. As a result, the focus is mainly on women and their struggle to combine paid and unpaid work. In response to criticism that this is a rather unbalanced approach, the government implemented 'Plan of the man', which contains ten parts referring to different topics such as leave facilites, the role of companies and their cultures, and male role models (OCW 2008). Regarding leave facilities, in 2009 the period of parental leave was doubled from 13 to 26 weeks; moreover, the leave is now partly paid, though at a low level. The 'Plan of the man' also proposes extending paternity leave, which is currently two days of paid lecve to be taken within four weeks following the birth. Other policy two das of For example, companies will be stimulated to offer employees more opportunities to combine work and family life (Plantenga and Remery cited in Fagan 2010).

\section{References}

Advisory Committee on Equal Opportunities between Women and Men (2006) 'Opinion on men in gender ecuality', submitted to the European Commission, July.

Aguiar, M., Hurst, E. and Karabarbounis, L. (2011) 'Time use during recessions', National Bureau of Economic Research Working Paper Series.

Anxo, D., Fagan, C., Smith, M., Letablier, M.T. and Perraudin, C. (2007) 'Parental leave in European countries: establishment survey on working-time 2004-5', European Foundation for the Improvement of Living and Working Conditions. 


\section{C. Fagan and H. Norman}

Arrighi, B. and Maume, D. (2000) 'Workplace subordination and men's avoidance of housework', Journal of Family Issues, 21(4): 464-87.

Benjamin, O. and Sullivan, O. (1997) 'The importance of difference: conceptualizing increased flexibility in gender relations at home', Sociological Review, 44: 225-51.

Bergman, H. and Hobson, B. (2002) 'Compulsory fatherhood: the coding of fatherhood in the Swedish welfare state', in B. Hobson (ed.), Making Men into Fathers: Men, Masculinities and the Social Politics of Fatherhood, Cambridge: Cambridge University Press.

Berthoud, R. (2009) 'Patterns of non-employment, and of disadvantage, in a recession' ISER Working Paper No. 2009-23, University of Essex.

Bettio, F. and Verashchagina, A. (2009) Gender Segregation in the Labour Market: Roots Causes, Implications and Policy Responses in the EU, Brussels: EU Expert Group on Gender and Employment (EGGE), European Commission.

Bettio, F. and Verashchagina, A. (2010) Long-term Care for the Elderly: Provisions and Providers in 33 European Countries, Brussels: EU Expert Group on Gender and Employment (EGGE), European Commission.

Bianchi, S., Milkie, M., Sayer, L. and Robinson, J. (2000) 'Is anyone doing the housework? Trends in the gender division of household labour', Social Forces, 79(1): $191-228$.

Bradley, H. (1993) 'Across the great divide: the entry of men into "women's jobs", in C. Williams (ed.), Doing 'Women's Work': Men in Nontraditional Occupations, Newbury Park, CA: Sage.

Brandth, B. and Kvande, E. (1998) 'Masculinity and childcare: the reconstruction of fathering', Sociological Review, 46(2): 293-313.

Brandth, B. and Kvande, E. (2003) 'Father presence in childcare', in A.M. Jensen and L. McKee (eds), Children and the Changing Family, London: Routledge Falmer.

Brandth, B. and Kvande, E. (2009) 'Gendered or gender-neutral care politics for fathers?', The Annals of the American Academy, 624: 177-89.

Bruegel, I. (2000) 'No more jobs for the boys? Gender and class in the restructuring of the British economy', Capital and Class, 71: 79-102.

Bruning, G. and Plantenga, J. (1999) 'Parental leave and equal opportunities: experiences in eight European countries', Journal of European Social Policy, 9(3): 195-209.

Burchell, B., Fagan, C., O'Brien, C. and Smith, M. (2007) European Foundation for the Improvement of Living and Working Conditions, Gender and Working Conditions in the European Union, Luxembourg: Office for Official Publications of the European Union.

Cameron, C., Candapapa, M., Mooney, A., McQuail, S., Moss, P. and Petrie, P. (2003) 'Early years and childcare international evidence project', DfES/SureStart Research Report.

CEC (2009) European Commission Takes Legal Action Against Hungary on Parental Leave, Brussels: Commission for the European Communities. Online. Available: http:// ec.europa.eu/social/main.jsp?langId=en\&catId=89\&newsId=627 (accessed 5 September 2011).

Coltrane, S. and Parke, R. (1998) Reinventing Fatherhood: Toward an Historical Understanding of Continuity and Change in Men's Family Lives, Philadelphia, PA: Nationa Center on Fathers and Families.

Council of the European Union (2006) 'Draft Council conclusions on men and gender equality', 14845/06 Soc 507, November.

Council of the European Union (2008) 'Review of the implementation by the Member States and the EU institutions of the Beijing Platform for Action - Reconciliation of
Men and gender equality 219

work and family life - Draft Council Conclusions, Report by the French Presidency on the indicators concerning reconciliation of work and family life included in the set of conclusions adopted by the Council under the French Presidency in 2000', 16070/08 SOC 708 .

Council of the European Union (2009) 'Proposal for a Council Directive implementing the revised Framework Agreement on parental leave concluded by BUSINESSEUROPE, UEAPME, CEEP and ETUC and repealing Directive 96/34/EC as amended by Directive 97/75/EC (text with EEA relevance) - Political agreement', 15994/09, SOC 699, 24 November.

Council of the European Union (2010) 'Council extends parental leave', Press release, Brussels, 8 March, 6641/10. Online. Available: www.consilium.europa.eu/uedocs/ cms_data/docs/pressdata/en/lsa/113206.pdf (accessed 8 November 2012).

COWI (2008) 'Directorate General Employment, Social Affairs and Equal Opportunities Study on the costs and benefits of options to improve provisions for the reconciliation of work, private and family life', Main Report, June, in collaboration with Ideas Consult.

Craig, L. (2007) 'Is there really a second shift, and if so, who does it? A time diary investigation', Feminist Review 86: 149-70.

Crompton, R. (2006) Employment and the Family: Reconfiguration of Work and Families in Contemporary Societies, Cambridge: Cambridge University Press.

Crompton, R. and Lyenette, C. (2008) 'Who does the housework? The division of labour within the home', in A. Park et al. (eds), British Social Attitudes 2007/8, the 24th Report, London: Sage.

Cross, S. and Bagilhole, B. (2002) 'Girls' jobs for the boys? Men, masculinity and nontraditional occupations', Gender, Work and Organization, 9(2): 204-26.

Del Bono, E., Sala, E. and Hancock, R. (2009) 'Older carers in the UK: are there really gender differences? New analysis of the individual sample of anonymised records from the 2001 UK Census', Health and Social Care in the Community, 17(3): 267-73.

Dermott, E. (2008) Intimate Fatherhood: A Sociological Analysis, London: Routledge.

Doucet, A. (2006) "“Estrogen-filled worlds": fathers as primary caregivers and embodiment', The Sociological Review, 54(4): 696-716.

Ellina, C. (2009) Gender Assessment of the National Reform Programme on Employment: Report on Cyprus, External report commissioned by and presented to the European Commission Directorate-General for Employment, Social Affairs and Equal Opportunities, Unit G1 'Equality between women and men'.

Ellingsater, A.L. (2009) 'Leave policy in the Nordic countries: a "recipe" for high employment/high fertility?', Community, Work \& Family, 12: 1-20.

Equality and Human Rights Commission (2009) Working Better: Fathers, Family and Work-Contemporary Perspectives, Manchester: EHRC.

European Commission (2010) Gender Equality in the EU in 2009, Special Eurobarometer 326/Wave 72.2- TNS Opinion \& Social, Brussels: Directorate-General for Communication ('Research and Political Analysis') Unit. Online. Available: http://ec. europa.eu/public_o jinion/archives/ebs/ebs_326_en.pdf (accessed 12 May 2011).

Eurostat (2009) Reconciliation of Work, Private and Family Life in the European Union, Luxembourg: Eurojean Commission.

Evans, J. (1997) 'Men in nursing: issues of gender segregation and hidden advantage', Journal of Advanced Nursing, 26: 226-31.

Evertsson, M. and Ne:mo, M. (2007) 'Changing resources and the division of housework: a longitudinal study of Swedish couples', European Sociological Review, 23(4): $455-70$. 


\section{C. Fagan and H. Norman}

Fagan, C. (2003) Working-Time Preferences and Work-Life Balance in the EU: Some Policy Considerations for Enhancing the Quality of Life, Dublin: European Foundation for the Improvement of Living and Working Conditions.

Fagan, C. (2010) 'Analysis note: men and gender equality tackling gender segregated family roles and social care jobs', European Commission.

Fagan, C. and Walthery, P. (2007) 'The role and effectiveness of time policies for reconciliation of care responsibilities', in OECD (ed.), Modernising Social Policy for the New Life Course, Paris: OECD.

Fagan, C., Hegewisch, A. and Pillinger, J. (2006) 'Out of time: why Britain needs a new approach to working time flexibility', Research paper for the Trades Union Congress, European Work and Employment Research Centre, University of Manchester.

Gaertner, B., Spinrad, T., Eisenberg, N. and Greving, K. (2007) 'Parental childrearing attitudes as correlates of father involvement during infancy', Journal of Marriage and Family, 69(November): 962-76.

Gershuny, J. (2000) Changing Times: Work and Leisure in Postindustrial Society, Oxford: Oxford University Press.

Gershuny, J., Godwin, M. and Jones, S. (1994) 'The domestic division of labor: a process of lagged adaptation?', in M. Anderson, F. Bechhofer and J. Gershuny (eds) The Social and Political Economy of the Household, Oxford: Oxford University Press.

Gottfredson, L. (1981) 'Circumscription and compromise: a developmental theory of occupational aspirations', Journal of Counselling Psychology, 28(6): 545-79.

Guardian (21 February 2009) 'Family policies 'dad-proofed' to give fathers bigger role - but no extra paternity leave'. Online. Available: www.guardian.co.uk/politics/2009/ $\mathrm{feb} / 21 /$ fathers-family-policy-government (accessed 5 September 2011).

Haas, L. and Hwang, C.P. (2008) 'The impact of taking leave on fathers' participation in childcare and relationships with children: lessons from Sweden', Community, Work \& Family, 11: 85-104.

Hatten, W., Vinter, L. and Williams, R. (2002) Dads on Dads: Needs and Expectations at Home and at Work, London: EOC.

Hearn, J. (2001) 'Men and gender equality: resistance, responsibilities and reaching out', Keynote paper at 'Men and Gender Equality' conference, Sweden, Örebro, March.

Heikes, J. (1992) 'When men are in the minority: the case of men in nursing', The Sociological Quarterly, 32(3): 389-401.

HM Government (2012) Modern Workplaces - Government Response on Flexible Parental Leave, London: Department for Business, Skills and Innovation.

Hobson, B., Drobníc, S. and Fagan, C. (2012) 'Sen's capabilities and agency framework applied to work-life balance across European welfare states and within work organizations', Social Politics, 18(2): 269-99.

Hochschild, A. (1989) The Second Shift, New York: Penguin Books.

Hook, J. (2006) 'Care in context: men's unpaid work in 20 countries, 1965-2003', American Sociological Review, 71: 639-60.

Jonsdottir, S. (2008) 'National report on the Icelandic experience of parental leave provision and the parental leave system in Iceland', Seminar reports, 22-23 October 2008, Focus Consultancy and Gopa Cartermill.

Kilkey, M. (2006) 'New Labour and reconciling work and family life', Social Policy and Society 5(2): 167-75.
Men and gender equality

\section{1}

Kitterod, R. and Petterson, S. (2006) 'Making up for mothers' employed working hours? Housework and childcare among Norwegian fathers', Work, Employment and Society, 20(3): 473-92.

Lader, D., Short, S. and Gershuny, J. (2006) The Time Use Survey 2005: How We Spend Our Time, London: Office for National Statistics.

Lammi-Taskula, J. (2006) 'Men on parental leave: can the welfare state change gender relations?', in A.L. Ellingsæter and A. Leira (eds), Politicising Parenthood in Scandinavia, Bristol: Policy Press.

Lewis, J. (2002) 'The problem of fathers: policy and behaviour in Britain', in B. Hobson (ed.), Making Men into Fathers: Men, Masculinities and the Social Politics of Fatherhood, Cambridge: Cambridge University Press.

Lohmann, H., Peter, F.H., Rostgaard, T. and Spiess, C. (2009) 'Towards a framework for assessing family policies in the EU', OECD Social Employment and Migration working papers No. 88, Directorate for Employment, Labour and Social Affairs.

Lupton, B. (2000) 'Maintaining masculinity: men who do women's work', British Journal of Management, 11: S33-S48.

MacDougall, G. (1997) 'Caring: a masculine perspective', Journal of Advanced Nursing, 25(4): 809-13.

McDowell, L. (1997) Capital Culture: Gender at Work in the City, Oxford: Blackwell.

Maier, F. (Andrea Filla-Carl research assistance) (2008) 'Gender assessment of the National Reform Programme on Employment: report on Germany', External report commissioned by and presented to the European Commission Directorate-General for Employment, Social Affairs and Equal Opportunities, Unit G1 'Equality between women and men'.

Marx-Ferree, M. (1991) 'The gender division of labour in two-earner marriages: dimensions of variability and change', Journal of Family Issues, 12: 158-80.

Metcalfe, B.D. and Afanassieva, M. (2005) 'Gender, work, and equal opportunities in Central and Eastern Europe', Women in Management Review 20(6): 397-411.

Morris, L.D. (1985) 'Responses to redundancy: labour-market experience, domestic organisation and male social networks', International Journal of Social Economics, 12(2): 5-16.

Moss, P. (2009) 'International review of leave policies and related research 2009', Employment Relations Research Series No. 102, Department for Business Innovation and Skills.

Moss, P. and Deven, F. (eds) (1999) Parental Leave: Progress or Pitfall? Research and policy Issues in Europe, Brussels: NIDI/CBGS publications.

Moss, P. and O'Brien, M. (2006) 'International review of leave policies and related research', Employment Relations Research Series No. 57, Department of Trade and Industry.

Norman, H. (2010) 'nnvolved fatherhood: an analysis of the conditions associated with paternal involvement in childcare and housework', Doctoral Thesis, University of Manchester.

Norwegian Ministry of Children, Equality and Social Inclusion (2009) 'Men, male roles and gender equality", White Paper. Online. Available: www.regjeringen.no/en/dep/bld/ Topics/Equality/men-and-genderequality/men-and-gender-equality.html?id=547951 (accessed 26 January 2010).

Nyberg, A. (2003) 'Economic crisis and the sustainability of the dual earner dual carer model', Working Faper presented to the ESRC seminar, University of Manchester 31 October. 


\section{C. Fagan and H. Norman}

Oakley, A. (1985) The Sociology of Housework, Oxford: Basil Blackwell.

O'Brien, M. (2005) 'Shared caring: bringing fathers into the frame', Working paper Series No. 18, Equal Opportunities Commission.

O'Brien, M. (2009) 'Fathers, parental leave policies and infant quality of life: international perspectives and policy impact', The Annals of the American Academy of Political and Social Science, Special Issue, Fathering Across Diversity and Adversity, 624: 190-213.

O'Brien, M., Brandth, B. and Kvande, E. (2007) 'Fathers, work and family life: global perspectives and new insights', Community, Work and Family 10(4): 375-86.

OCW (2008). Plan van de man, Den Haag: Ministerie van Onderwijs, Cultuur \& Wetenschap.

Official Journal of the European Communities (2010) 'Council Directive 2010/18/EU of 8 March 2010 implementing the revised Framework Agreement on parental leave concluded by BUSINESSEUROPE, UEAPME, CEEP and ETUC and repealing Directive 96/34/EC L68/13', 18 March.

Owen, C. (2003) Men's Work? Changing the Gender Mix of the Childcare and Early Years Workforce. London: Daycare Trust.

Penn, H. and McQuail, S. (1997) Childcare as a Gendered Occupation, London: HMSO.

Piscová, M. and Bahna, M. (2009) 'Gender Assessment of the National Reform Programme on Employment: Report on Slovakia', External report commissioned by and presented to the European Commission Directorate-General for Employment, Social Affairs and Equal Opportunities, Unit G1 'Equality between women and men'.

Plantenga, J. and Remery, C. (2005) Reconciliation of Work and Private Life: A Comparative Review of Thirty European Countries, Luxembourg: Office for Official Publications of the European Communities.

Plantenga, J. and Remery, C. (2009) The Provision of Childcare Services: A Comparative Review of 30 European Countries, Brussels: European Commission.

Plantenga, J., Remery, C. and Rubery, J. (2007) Gender Mainstreaming of Employment Policies: A Comparative Review of Thirty European Countries, Luxembourg: Official Publications of the European Communities.

Riedmann, A., Bielenski, H., Szczurowska, T. and Wagner, A. (2006) Working Time and Work Life Balance in European Companies, Luxembourg: Office for Official Publications of the European Communities.

Rolfe, H. (2006) 'Where are the men? Gender segregation in the childcare and early years sector', National Institute Economic Review 195: 103-17.

Rubery, J. and Fagan, C. (1993) Occupational Segregation of Women and Men in the European Community, Luxembourg: Office for Official Publications of the European Communities.

Rubery, J. and Fagan, C. (1995) 'Gendered relations in societal context' Work, Employment and Society, 9(2): 213-40.

Scott, J. (2006) 'Family and gender: how attitudes are changing', GeNet Working Paper No. 21.

Segal, L. (1990) Slow Motion: Changing Masculinities, Changing Men, London: Virago.

Simpson, R. (2004) 'Masculinity at work: the experiences of men in female dominated occupations', Work, Employment and Society, 18(2): 349-68.

Smeaton, D. (2006) 'Dads and their babies: a household analysis', Working Paper Series, Equal Opportunities Commission.

Smith, A. and Williams, D. (2007) 'Father friendly legislation and paternal time across Western Europe', Journal of Comparative Policy Analysis, 9(2): 175-92.
Men and gender equality 223

Smith, M. (2009) 'Anal sis note: gender equality and recession'. Online. Available: http://eppwomen.org/images/dbimages/docs/Equality-crisis-final[1].pdf (accessed 5 September 2011)

Spain, D. and Bianchi, S. (1996) Balancing Act: Motherhood, Marriage and Employment among American Women, New York: Russell Sage Foundation.

Stier, H. and Lewin-Epstein, N. (2007) 'Policy effects on the division of housework', Journal of Comparative Policy Analysis, 9(3): 235-59.

Sullivan, O., Coltrane, S., Mcannally, L., and Altintas, E. (2009) 'Father-friendly policies and time-use data in a cross-national context: potential and prospects for future research', Annals of the American Academy of Political and Social Science, 624(1): $234-54$.

Tanaka, S. and Waldfogel, J. (2007) 'Effects of parental leave and work hours on fathers' involvement with their babies', Community, Work and Family, 10(4): 409-26.

Wacjman, J. (1998) Managing Like a Man: Women and Men in Corporate Management, Oxford: Polity Press.

Williams, C. (1992) "The glass escalator: hidden advantages for men in the "female" professions', Social Problems, 39(3): 253-67.

Young, H., Grundy E. and Jitlal, M. (2006) Care Providers, Care Receivers: A Longitudinal Perspective, Yok: Joseph Rowntree Foundation. 